\title{
目
}

Arch. Min. Sci. 62 (2017), 1, 45-54

Electronic version (in color) of this paper is available: http:/mining.archives.pl

DOI 10.1515/amsc-2017-0004

\section{STANISŁAW WOLNY*}

\section{EMERGENCY BRAKING OF A MINE HOIST IN THE CONTEXT OF THE BRAKING SYSTEM SELECTION}

\author{
HAMOWANIE AWARYJNE (KRAŃCOWE) URZĄDZENIA WYCIĄGOWEGO \\ - DOBÓR UKLADU HAMUJĄCEGO
}

The paper addresses the selected aspects of the dynamic behaviour of mine hoists during the emergency braking phase. Basing on the model of the hoist and supported by theoretical backgrounds provided by the author (Wolny, 2016), analytical formulas are derived to determine the parameters of the braking system such that during an emergency braking it should guarantee that:

- the maximal loading of the hoisting ropes should not exceed the rope breaking force,

- deceleration of the conveyances being stopped should not exceed the admissible levels

Results of the dynamic analysis of the mine hoist behaviour during an emergency braking phase summarised in this study can be utilised to support the design of conveyance and rope attachments by the fatigue endurance methods, with an aim to adapt it to the specified operational parameters of the hoisting installation (Eurokod 3).

Keywords: mine hoists, dynamics, loading, emergency braking

W referacie przedstawiono wybrane problemy dynamiczne związane $\mathrm{z}$ awaryjnym (krańcowym) hamowaniem naczyń wydobywczych górniczego urządzenia wyciagowego. Bazując na modelu urządzenia oraz rozważaniach zawartych w opracowaniu autora (Wolny, 2016) podano wzory analityczne z pomocą których można wyznaczyć parametry układu hamującego, którego zastosowanie do awaryjnego (krańcowego) hamowania, gwarantuje że:

- maksymalne obciążenie lin nośnych nie przekroczy wartości siły zrywającej liny,

- opóźnienie hamowanych naczyń nie przekroczy opóźnienia dopuszczalnego.

Wyniki analizy dynamicznej pracy urządzenia wyciagowego w warunkach hamowania (krańcowego) awaryjnego, zawarte w referacie mogą stanowić podstawy do poprawnego zaprojektowania np. elementów zawieszeń naczyń i lin wyrównawczych, również z wykorzystaniem metod wytrzymałości zmęczeniowej, dla konkretnych parametrów eksploatacyjnych wyciągu (Eurokod 3).

Słowa kluczowe: wyciąg górniczy, dynamika, obciążenia, hamowanie awaryjne 


\section{Introduction}

Emergency braking cycles when the braking force is applied directly to conveyances which have begun an overtravel have already received a great deal of attention from researchers (Wolny, 1988, 2003). However, no analytical formulas are provided which could be used to determine the parameters of the braking system such that it guarantee that the maximal loading of the hoisting ropes should not exceed the rope breaking force and that the deceleration of the conveyances being stopped should not exceed the admissible level. This statement refers to analytical studies only because some attempts have been made to handle the problem by numerical methods (Klich, 1980). The numerical data: displacements of selected model points in the conditions of emergency braking in relation to predetermined parameters of the braking system can be derived, though the accuracy of the model has to be taken into account as well. Though useful for the practitioners, obviously such solutions could not be used in the analysis of the system's sensitivity to variations in input parameters (parameters of the braking system) during the emergency braking in an event of an overtravel.

This study is focused on finding an analytical solution the outlined problem, or in other words, its purpose is to determine the displacements of the hoisting and tail ropes' cross-profiles in the two conveyances during an emergency braking phase in the function of parameters of the braking system by analytical methods. The solutions are underpinned by theoretical backgrounds and use the hoist model provided in the work by (Wolny, 2016).

This study is limited to finding the maximal loads acting on the hoisting ropes and deceleration of the conveyances in the event of emergency braking using the system whose characteristic is given in Fig. 1.

This characteristic of the braking system is corroborated by the results of dynamic testing done on braking system solutions in widespread use in Poland and world-wide (Wolny, 2003).

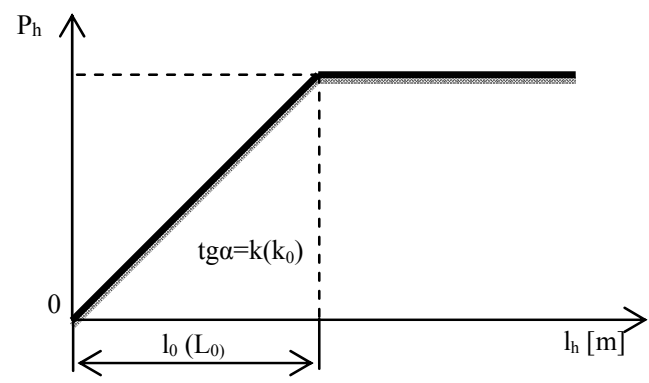

Fig. 1. Dynamic characteristic of the braking system; $l_{0}\left(L_{0}\right)$ - distance of braking force increase: $K\left(k_{0}\right)-$ coefficient expressing the braking force increase; $t_{0}\left(T_{0}\right)$ - time of the braking force increase over the distance $l_{0}\left(L_{0}\right)$, $P_{h}$ - braking force, $l_{h}$ - braking distance

\section{Emergency braking of mine hoists}

The work by (Wolny, 2016) provides analytical formulas to derive the displacements of any cross-profiles of hoisting and tail ropes during an emergency braking phase, i.e. whilst the braking force is applied to act on the conveyance. 
Recalling (Wolny, 2016), these formulas can be given in a simplified form, following an assumption that:

$$
\begin{gathered}
\frac{A_{w} E_{w}}{a_{w}} \cong \frac{A_{N} E_{N}}{a_{N}}=\frac{A E}{a}, \\
M_{0} \cong M_{1}=M
\end{gathered}
$$

This assumption holds true for tower - type gears, which was verified in practical applications (Knop, 1975).

Accordingly, we get:

$$
\omega_{10}^{2}=\frac{A_{N} E_{N}}{M_{0} l_{1}} ; \omega_{11}^{2}=\frac{A_{N} E_{N}}{M_{1} l_{1}} ; 2 h_{0}=\frac{A_{N} E_{N}}{M_{0} a_{N}} ; 2 h_{1}=\frac{A_{w} E_{w}}{M_{1} a_{w}}
$$

In consequence we get the following equalities:

$$
\begin{aligned}
& h_{1} \cong h_{0}=h, \\
& \omega_{10} \cong \omega_{11}=\omega_{0}
\end{aligned}
$$

Finally, the dependencies expressing the displacements of rope cross-profiles can be written as:

- for tail ropes

$$
\begin{aligned}
& u^{*}(x, t)=\frac{k \cdot V_{0}}{8 M_{1}}\left\{\begin{array}{l}
\frac{1}{h}\left(t-\frac{x}{a_{w}}\right)^{2}+\frac{2 h^{2}-\omega_{0}^{2}}{h^{2} \omega_{0}^{2}}\left(t-\frac{x}{a_{w}}\right)++ \\
\frac{\omega_{0}^{4}-4 h^{4}}{2 \omega_{0}^{4} h^{3}} u\left(t-\frac{x}{a_{w}}\right)-\frac{1}{2 h^{3}} \cdot e^{-2 h\left(t-\frac{x}{a_{w}}\right)}+ \\
+\frac{2}{\omega_{0}^{2} \sqrt{2 \omega_{0}^{2}-h^{2}}} \cdot e^{-h\left(t-\frac{x}{a_{w}}\right)} \sin \left[\sqrt{2 \omega_{0}^{2}-h^{2}}\left(t-\frac{x}{a_{w}}\right)+\Phi_{2}\right]
\end{array}\right\}+ \\
& \left(\frac{1}{h}\left(t+\frac{x-2 l_{w}}{a_{w}}\right)^{2}+\frac{2 h^{2}-\omega_{0}^{2}}{h^{2} \omega_{0}^{2}}\left(t+\frac{x-2 l_{w}}{a_{w}}\right)++\right. \\
& +\frac{k \cdot V_{0}}{8 M_{1}}\left\{\frac{\omega_{0}^{4}-4 h^{4}}{2 \omega_{0}^{4} h^{3}} u\left(t+\frac{x-2 l_{w}}{a_{w}}\right)-\frac{1}{2 h^{3}} \cdot e^{-2 h\left(t+\frac{x-2 l_{w}}{a_{w}}\right)}+\right. \\
& \left.+\frac{2}{\omega_{0}^{2} \sqrt{2 \omega_{0}^{2}-h^{2}}} \cdot e^{-h\left(t+\frac{x-2 l_{w}}{a_{w}}\right)} \sin \left[\sqrt{2 \omega_{0}^{2}-h^{2}}\left(t+\frac{x-2 l_{w}}{a_{w}}\right)+\Phi_{2}\right]\right]
\end{aligned}
$$


- for hoisting ropes:

$$
\begin{aligned}
& v^{*}(y, t)=-\frac{k \cdot V_{0}}{8 M_{1}}\left\{\begin{array}{l}
\frac{1}{h}\left(t-\frac{y}{a_{N}}\right)^{2}-\frac{2 h^{2}+\omega_{0}^{2}}{h^{2} \omega_{0}^{2}}\left(t-\frac{y}{a_{N}}\right)+ \\
+\frac{\omega_{0}^{4}+4 h^{4}}{2 \omega_{0}^{4} h^{3}} u\left(t-\frac{y}{a_{N}}\right)-\frac{1}{2 h^{3}} \cdot e^{-2 h\left(t-\frac{y}{a_{N}}\right)}+ \\
-\frac{2}{\omega_{0}^{2} \sqrt{2 \omega_{0}^{2}-h^{2}}} \cdot e^{-h\left(t-\frac{y}{a_{N}}\right)} \sin \left[\sqrt{2 \omega_{0}^{2}-h^{2}}\left(t-\frac{y}{a_{N}}\right)+\Phi_{2}\right]
\end{array}\right\}+ \\
& -\frac{k_{0} \cdot V_{0}}{M_{2} \omega_{2}^{4}}\left\{\begin{array}{l}
\omega_{2}^{2}\left(t+\frac{y-l_{N}}{a_{N}}\right)-2 h \cdot u\left(t+\frac{y-l_{N}}{a_{N}}\right)+ \\
+\frac{\omega_{2}^{2}}{\sqrt{\omega_{2}^{2}-h^{2}}} \cdot e^{-h_{2}\left(t+\frac{y-l_{N}}{a_{N}}\right)} \sin \left[\sqrt{\omega_{2}^{2}-h_{2}^{2}}\left(t+\frac{y-l_{N}}{a_{N}}\right)+\Phi_{1}\right]
\end{array}\right\}
\end{aligned}
$$

where:

$$
\begin{aligned}
& \Phi_{2}=\frac{\pi}{2}+\operatorname{acrtg} \frac{h^{2}-\omega_{0}^{2}}{h \sqrt{2 \omega_{0}^{2}-h^{2}}}, \\
& \Phi_{1}=\frac{\pi}{2}+\operatorname{arctg} \frac{\omega_{2}^{2}-2 h_{2}^{2}}{2 h_{2} \sqrt{\omega_{2}^{2}-h_{2}^{2}}},
\end{aligned}
$$

and

$$
\omega_{2}^{2}=\frac{k_{0}}{M_{2}} ; 2 h_{2}=\frac{A_{N} E_{N}}{M_{2} a_{N}}
$$

$u^{*}(x, t) ; v^{*}(y, t)$ are respective displacements of cross-profiles of tail ropes and hoisting ropes at the distant of $x, y$ from the mobile coordinate systems associated with the mass $M_{0}$ and $M_{1}$ (for $t=0$ ). Those displacements are calculated in the coordinate systems whose origins at the instant $t=0$ coincide with the masses $M_{0}$ and $M_{1}$ and which move at the velocity $V_{0}=$ const, which is the speed with which all hoists elements move at the initial moment, and

$l_{1}$ _ length of the hoisting rope section between the conveyance being stopped in the headgear tower and the Koepe pulley at the instant the emergency braking phase begins (Fig. 1),

$V_{0}$ - velocity of the conveyance beginning an overtravel,

$A_{W} E_{W}, A_{N} E_{N}$ - tensile rigidity of tail ropes and hoisting ropes, respectively,

$k, k_{0}$ - coefficients expressing the braking force increase in the tower and at the pit bottom, respectively (Wolny, 1988). 


\section{Emergency braking effects}

In the light of major consequence of emergency braking, these aspects seem to be of key importance:

- loads acting upon a short section of hoisting ropes between the conveyance being arrested in the headgear tower and the Keope pulley so that the frictional contact between the hoisting rope and the pulley should not be disturbed, and in consideration of the fact that the length of this rope section may become zero,

- deceleration of conveyances being arrested in the headgear tower or at the pit bottom should not exceed the admissible levels

\subsection{Maximal loads acting on the rope section between the conveyance being arrested in the headgear tower and the Keope pulley}

Loads acting upon this section of the hoisting rope in the first stage of the emergency braking phase (until the return of the elastic deformation wave) can be obtained from the formula (Wolny, 2016):

$$
S_{l_{N}}^{*}=\frac{A_{N} E_{N}}{l_{1}}\left[u^{*}(x=o, t)+v^{*}(y=o, t)\right]
$$

Recalling Eq. (1) and (2), after necessary transformation Eq. (3) becomes:

$$
S_{l_{N}}^{*}=\frac{A_{N} E_{N}}{l_{1}} \frac{k \cdot V_{0}}{M_{1}}\left\{\frac{1}{2 \omega_{0}^{2}} t-\frac{1}{2} \frac{h}{\omega_{0}^{4}}+\frac{1}{2} \frac{e^{-h t}}{\omega_{0}^{2} \sqrt{2 \omega_{0}^{2}-h^{2}}} \cdot \sin \left[\sqrt{2 \omega_{0}^{2}-h^{2}} t+\Phi_{2}\right]\right\}
$$

The extreme value of the expression (4) is found for the time $t$, given by the formula:

$$
t=\frac{1}{\sqrt{2 \omega_{0}^{2}-h^{2}}} \operatorname{arctg} \frac{h}{\sqrt{2 \omega_{0}^{2}-h^{2}}}
$$

The extreme value of (4) is expressed by the following dependence:

$$
S_{l_{N_{\max }}}^{*}=\frac{k \cdot V_{0}}{2} \cdot \frac{h}{\omega_{0}^{2}}\left\{\frac{\omega_{0}^{2}}{2 \omega_{0}^{2}-h^{2}} \cdot\left[1+\sqrt{1-\left(\frac{h}{2 \omega_{0}}\right)^{2}}\right]-1\right\}
$$

Rearranging, we get:

$$
S_{l_{N_{\max }}}^{*}=\frac{k \cdot V_{0}}{2} \cdot \frac{l_{1}}{2 a}\left\{\frac{1}{2-\left(\frac{A E}{2 M a}\right) \cdot\left(\frac{l_{1}}{2 a}\right)} \cdot\left[1+\sqrt{1-\frac{1}{4}\left(\frac{A E}{2 M a}\right) \cdot\left(\frac{l_{1}}{2 a}\right)}\right]-1\right\}
$$


Limiting the load acting upon this rope section such that it should not exceed the rope breaking force is one of the basic conditions underlying the selection of parameters of the braking system, guaranteeing its safe operation.

This condition can be expressed as:

$$
S_{l_{N_{\max }}}^{*} \leq S_{Z_{l_{N}}}
$$

where: $S_{Z_{l_{N}}}$ force breaking the hoisting ropes.

Recalling Eq. (7), the dependence (8) gives the value of the parameter $k$, governing the behaviour of the braking system in the overtravel zones, ensuring its correct performance and preventing rope breaking.

The value of the parameter $k$ for the device arresting the conveyance in the headgear tower is given by:

$$
k \leq \frac{S_{Z_{l_{N}}}}{\frac{V_{0}}{2} \cdot \frac{l_{1}}{2 a}\left\{\frac{1}{2-\left(\frac{A E}{2 M a}\right) \cdot\left(\frac{l_{1}}{2 a}\right)} \cdot\left[1+\sqrt{1-\frac{1}{4}\left(\frac{A E}{2 M a}\right) \cdot\left(\frac{l_{1}}{2 a}\right)}\right]-1\right\}}
$$

The inequality (9) involves certain hoist parameters which are beyond control of those responsible for engineering design of the braking systems, including:

- $a \cong 3700 \mathrm{~m}$ - velocity of elastic wave propagation in ropes

- $E \cong 1,1 \cdot 10^{5} \mathrm{MPa}$ - modulus of elasticity (the velocity of elastic wave propagation in ropes is calculated based on this value)

- $l_{1}=(30 \div 50) \mathrm{m}-$ length of the hoisting rope section between the conveyance being arrested in the headgear tower and the Koepe pulley at the instant the emergency braking phase begins (for typical tower-type gears operated in most collieries in Poland)

As regards the remaining parameters present in formula (9), the cross-profile of hoisting ropes, denoted by $A$ and dependent on the payload $Q_{u}$ and the weight of the conveyance with all necessary equipment $Q_{m}$, is expressed as the total mass $\mathrm{M}$ of the conveyance with payload, in accordance with the relevant provisions of the Regulation by the Minister of Economy (2002). The value of the expression $A E / 2 M a$ falls in the range $0,8 \div 1,21 / \mathrm{s}$ and $l_{1} / 2$ a ranges from 4 to $7 \cdot 10^{-3}[\mathrm{~s}]$.

Thus, the value of the expression

$$
\left\{\frac{1}{2-\left(\frac{A E}{2 M a}\right) \cdot \frac{l_{1}}{2 a}}\left[1+\sqrt{1-\frac{1}{4}\left(\frac{A E}{2 M a}\right) \cdot \frac{l_{1}}{2 a}}\right]-1\right\}
$$

falls in the range $(1 \div 3.75) \cdot 10^{-3}$ for most hoist installations operated in Polish collieries. Accordingly, inequality (9) becomes

$$
k \leq \frac{4 a}{V_{0} l_{1}} \cdot(3 \div 7) \cdot 10^{2} s_{z_{L N}}
$$


The expression (11) can be utilised to support the selection of the braking system where the value of the coefficient of braking force increase $k$ guarantees the secure arrest of the conveyance in the event of an overtravel and ensures the rope will not be broken.

The value of 3 should be adopted in the case of hoist installations where $\frac{A E}{2 M a} \geq 1,2\left[\frac{1}{s}\right]$ and $l_{1} \geq 1,50 \mathrm{~m}$ and the value of 7 - for installations in which $\frac{A E}{2 M a} \leq 0,8\left[\frac{1}{s}\right]$ and $l_{1} \leq 30 \mathrm{~m}$. The exact values of the parameter $k$ of the braking system should be derived basing on formula (9).

\subsection{Deceleration of conveyances being arrested}

Another aspect to be considered when selecting the parameters of the braking system is the need to restrict the deceleration of the conveyance during an emergency braking. For a conveyance being arrested in the head tower, this condition can be written as:

$$
a_{g}=\frac{\partial^{2} u^{*}(x=0, t)}{\partial t^{2}} \leq a_{d o p}
$$

where:

$a_{d o p}-$ admissible deceleration of conveyances being arrested (one in the topmost position and the other in the lowermost),

$u^{*}(x=0, t)$ - displacement of the top conveyance - formula (11) (Wolny, 2016).

In the event of emergency braking of the bottom conveyance, the condition (12) can be expressed as:

$$
a_{d}=\frac{\partial^{2} v^{*}(y=0, t)}{\partial t^{2}} \leq a_{d o p}
$$

where: $v^{*}(y=0, t)$ - displacement of the bottom conveyance during an emergency braking (given by formula (12) and substituting $y=0$ ) (Wolny, 2016).

Further analysis should be restricted to emergency braking of the conveyance in the headgear tower. Recalling formula (11) (Wolny, 2016), Eq (12) becomes:

$$
\begin{aligned}
a_{g} & =\frac{\partial^{2} u^{*}(x=0, t)}{\partial t^{2}}= \\
& =\frac{k V_{0}}{M}\left\{\frac{1}{4 h}-\frac{1}{4 h} e^{-2 h t}+\frac{1}{2} \cdot \frac{e^{-h t}}{\sqrt{2 \omega_{0}^{2}-h^{2}}} \cdot \sin \left[\sqrt{2 \omega_{0}^{2}-h^{2}} \cdot t\right]\right\}
\end{aligned}
$$

Designations as above.

The expression (14) has its extreme value for the time $t$, given by the formula:

$$
t=\frac{2}{\sqrt{2 \omega_{0}^{2}-h^{2}}} \arcsin \left(\frac{\sqrt{2 \omega_{0}^{2}-h^{2}}}{\sqrt{2} \omega_{0}}\right)
$$


Hence, the extreme deceleration of the top conveyance in the event of emergency braking can be obtained from the formula:

$$
a_{g}^{\max }=\frac{k V}{M}\left\{+\frac{1}{2} \cdot \frac{1}{\sqrt{2 \omega_{0}^{2}-h^{2}}} \exp \left(-\frac{2 h}{\sqrt{2 \omega_{0}^{2}-h^{2}}} \arcsin \frac{\sqrt{2 \omega_{0}^{2}-h^{2}}}{\sqrt{2} \omega_{0}}\right) \cdot \exp \left(-\frac{4 h}{\sqrt{2 \omega_{0}^{2}-h^{2}}}\right) \cdot\right\}
$$

After necessary substitutions and recalling $\omega_{0} \gg h$, the simplified expression (16) becomes:

$$
a_{g}^{\max }=\frac{k V_{0} a}{2 A E}\left[1-\exp \left(\frac{-2 \pi}{\sqrt{8 \cdot \frac{M a^{2}}{A E l_{1}}-1}}\right)\right]
$$

Reducing the deceleration of the conveyance being arrested in the head tower such that the admissible deceleration limit should not be exceeded is another major condition underlying the selection of parameters of the braking system, guaranteeing its safe operation. For the conveyance being arrested in the headgear tower, this condition can be written as:

$$
a_{g}^{\max } \leq a_{d o p}
$$

where: $a_{d o p}$ - admissible deceleration of a conveyance arrested in the headgear tower.

Recalling Eq. (18), the formula can be derived that gives the value of the parameter $k$, governing the behaviour of the braking system in the overtravel zones, ensuring its correct performance (and preventing the admissible deceleration levels from being exceeded).

$$
k \leq \frac{a_{d o p} a}{2 A E}\left[1-\exp \left(\frac{-2 \pi}{\sqrt{8 \cdot \frac{M a^{2}}{A E l_{1}}-1}}\right)\right]
$$

Similar to (9), the inequality (19) contains the same constant parameters of the hoist installation which are beyond control of design engineers responsible for the braking system design. 
Recalling that the value of $\frac{A E}{2 M a}$ falls in the range $(0,8 \div 1,2) 1 / \mathrm{s}$ and $l_{1} / 2 \mathrm{a}$ is in the range $(4 \div 7) \cdot 10^{-3} \mathrm{~s}$, the value of the expression

$$
\left[1-\exp \left(-\frac{2 \pi}{\left.\sqrt{8\left(\frac{M a}{A E}\right) \frac{a}{l_{1}}}\right)}\right]\right.
$$

will fall in the range $0.22 \div 0.32$.

Substituting into (19), we get:

$$
k \leq(3,0 \div 4,5) \frac{2 A E}{V_{0} a} \cdot a_{d o p}
$$

The expression (21) can be utilised to support the selection of the braking system where the value of the coefficient of braking force increase $k$ should guarantee the secure arrest of the conveyance in the event of an overtravel, preventing the admissible deceleration levels from being exceeded.

\section{Summing-up}

Th analysis of the dynamic behaviour of a mine hoist in an event of overtravel of a conveyance was conducted to derive the following parameters:

- maximal load acting upon a short section of a hoisting rope between the conveyance being arrested in the head tower and the Koepe pulley (including the loads acting on the conveyance attachments),

- maximal deceleration of a conveyance (this study is limited to finding the maximal deceleration of a conveyance being arrested in the head tower).

Analytical formulas are derived to determine the parameters of the braking system such that during an emergency braking phase it should guarantee that:

- the maximal loading of the hoisting ropes should not exceed the rope breaking force,

- deceleration of the conveyances being stopped should not exceed the admissible levels.

Results of the dynamic analysis of the mine hoist behaviour during an emergency braking phase summarised in this study can be utilised to support the design of conveyance and rope attachments by the fatigue endurance methods with an aim to adapt it to the specified operational parameters of the hoisting installation. 


\section{References}

Klich A., 1980. Modellerung Schachtfördranlagen für Grosse lasten und Teufen. Archiwum Górnictwa, 25, 2.

Knop H., 1975. Wybrane zagadnienia z dynamiki urządzeń wyciagowych. ZN AGH, Elektryfikacja i Mechanizacja Górnictwa i Hutnictwa, Z 67, Kraków.

Wolny S., 1988. Teoretyczne rozważania nad procesem hamowania krańcowego naczyń wydobywczych wyciagów kopalnianych. ZN AGH. Mechanika, z. 11. Kraków 1988.

Wolny S., 2003. Wybrane problemy wytrzymałościowe w eksploatacji górniczych urzadzeń wyciagowych. Monografia. Problems of mechanical engineering and robotics, No 20, Kraków 2003. s. 1-260.

Wolny S., 2016. Loads acting on the mine conveyance attachments and tail ropes during the energency braking in the event of on overtravel. Arch. Min. Sci. 61, 2, 497-507.

Rozporządzenie Ministra Gospodarki z dnia 28 czerwca 2002 r. w sprawie bezpieczeństwa i higieny pracy, prowadzenia ruchu oraz specjalistycznego zabezpieczenia przeciwpożarowego w podziemnych zakładach górniczych.

Eurokod 3. Projektowanie konstrukcji stalowych (w zastępstwie normy PN-90/B03200). 